\title{
Ring-widths of the above tree-line shrub Rhododendron reveal the change of minimum winter temperature over the past 211 years in Southwestern China
}

\author{
Yingfeng $\mathrm{Bi}^{1,2,3,4} \cdot$ Jianchu $\mathrm{Xu}^{1,2,4,5} \cdot$ Jinchao Yang ${ }^{6} \cdot$ Zongshan $\mathrm{Li}^{7}$. \\ Aster Gebrekirstos $^{8}$ - Eryuan Liang ${ }^{9}$ Shibao Zhang ${ }^{2,4} \cdot$ Yang Yang $^{1}$. \\ Yongping Yang $^{1} \cdot$ Xuefei Yang ${ }^{1,2,4,10}$
}

Received: 10 April 2016 / Accepted: 8 August 2016 / Published online: 20 August 2016

(C) The Author(s) 2016. This article is published with open access at Springerlink.com

\begin{abstract}
Changes in minimum winter temperature (MWT) and their potential effects on plant growth and development have been gaining increased scientific attention. To better understand these changes across long temporal scales, the present study used dendroclimatological techniques to assess variations in MWT in Southwestern China. Using data from Rhododendron species distributed in areas above the tree-line, a regional composite chronology was generated for a 341-year period. Based on the significant negative correlation between MWT values and ring-width, the most reliable parts of this chronological data were then used to reconstruct MWT values for the past 211 years. This reconstructed MWT series showed decadal to multi-decadal fluctuations. Three distinct cold periods prevailed during 1823-1858, 1882-1891 and 19221965, while four warm intervals occurred in 1800-1822,
\end{abstract}

Electronic supplementary material The online version of this article (doi:10.1007/s00382-016-3311-4) contains supplementary material, which is available to authorized users.

Xuefei Yang

xuefei@mail.kib.ac.cn

1 Key Laboratory of Plant Diversity and Biogeography of East Asia, Chinese Academy of Sciences, Kunming 650201, China

2 Key Laboratory of Economic Plants and Biotechnology, Kunming Institute of Botany, Chinese Academy of Sciences, Kunming 650201, China

3 University of Chinese Academy of Sciences, Beijing 100049, China

4 Yunnan Key Laboratory for Wild Plant Resources, Kunming 650201, China

5 World Agroforestry Centre (ICRAF), East and Central Asia, Kunming 650201, China
1858-1881, 1892-1921 and 1966-2011. Our reconstructed MWT reveals a warming trend over the most recent eight decades, which is in agreement with instrumental observations. However, the MWT values and rate of warming over the past seven decades did not exceed those found in the reconstructed temperature data for the past 211 years. Spatial correlations reveal that the MWT in Southwest China is strongly associated with regional temperatures in the Eastern and Central Himalaya, Northern China, and the Indian Peninsula. Larger scale climate oscillations of the Western Pacific and Northern Indian Ocean as well as the North Atlantic Oscillation probably influenced the region's temperature in the past.

Keywords Minimum winter temperature $\cdot$ Rhododendron Ring-width $\cdot$ Shrub $\cdot$ Southwestern China

6 Southwest Forestry University, Kunming 650224, China

7 State Key Laboratory of Urban and Regional Ecology, Research Center for Eco-Environmental Sciences, Chinese Academy of Sciences, Beijing 100085, China

8 World Agroforestry Centre (ICRAF), United Nations Avenue, Nairobi 00100, Kenya

9 Key Laboratory of Tibetan Environment Changes and Land Surface Processes, Institute of Tibetan Plateau Research, Chinese Academy of Sciences, Beijing 100101, China

10 Southeast Asia Biodiversity Research Institute, Chinese Academy of Sciences, Menglun, Mengla 666303, Yunnan, China 


\section{Introduction}

Winter temperatures have only recently been recognized as being more variable than annual and summer temperatures (Kreyling 2010). This has stimulated a growing interest in the critical effects of winter climatic conditions on terrestrial organisms (Caroline et al. 2015). Plants inhabiting temperate regions, high latitudes and high elevation regions depend greatly on the ecological processes which occur in winter, during which minimum winter temperature (MWT) acts as an important climatic cue (Kreyling 2010). MWT shapes the distribution and range of many species (Box et al. 1993; Matsui et al. 2004), acting as a major determinant of their performance and regulating community composition and ecosystem dynamics (Crumpacker et al. 2001; Schmitz 2004). Over the past several decades, increases in MWT have been reported worldwide, and this trend is expected to continue (IPCC 2014). Understanding past variations in MWT and their effects on the earth's ecosystems will be necessary for the accurate prediction of future changes and for the development of suitable responses and strategies for conservation in the context of climate change.

Tree-rings record the growth status of a woody plant over the whole period of its life cycle, which may last several centuries. Dendroclimatological studies are based on the statistical relationships between tree-ring parameters and climatic variables and have been widely employed to reconstruct past climatic variations beyond the availability of instrumental climate data. Hundreds of tree species have been analyzed during dendrochronological studies in the past several decades (Hughes et al. 2010; Yang et al. 2014). Climatic variables such as temperature ( $\mathrm{He}$ et al. 2014; Jacoby and Darrigo 1989; Zhang et al. 2015), precipitation (Touchan et al. 2014; Wilson et al. 2013; Yang et al. 2014) and Palmer Drought Severity Index (PDSI) (Bi et al. 2015; Cook et al. 2010; Fang et al. 2010b) have been reconstructed from tree-ring data.

Recently, shrub dendrochronology has been the focus of an increasing number of studies (Hallinger et al. 2010; Liang and Eckstein 2009; Liang et al. 2012; Myers-Smith et al. 2015). Dendrochronological studies on shrub species have been mainly conducted in the Arctic tundra, arid and semi-arid areas, and high mountain regions, including species such as Cassiope tetragona (Rayback et al. 2012), Salix arctica (Woodcock and Bradley 1994), Pteronia pallens (Milton et al. 1997), Arbutus unedo, Tamarix ramossima (Xiao et al. 2004), Rhododendron nivale (Liang and Eckstein 2009) and R. aganniphum (Lu et al. 2015). While most of these studies captured climate signals as far back as 200 years ago, a recent publication by Lu et al. (2015) provided a 341-year chronology that represents the longest shrub chronology available to date. Some of these shrub species are distributed above the tree-line, which is defined by Körner (2012) as a line connecting the middle positions of the highest patches of forest at a given site. Thus they provide an opportunity to extend tree-ring data to areas above the tree-line.

Southwestern China is particularly vulnerable to climate change (Xu et al. 2009). The region's complex landforms and topography result in a highly variable climate (Chan et al. 2013; Zhang et al. 2014). Based on meteorological records, winter temperatures in this region have been undergoing a warming trend at a rate of $0.35{ }^{\circ} \mathrm{C}$ per decade ( $\mathrm{Li}$ et al. 2011), and MWT is rising at a faster rate than annual and maximum winter temperatures (Fan et al. 2011; Liu et al. 2006). Studying the variation in long-term MWT in this region could help improve the understanding of regional climatic variations elsewhere. Southwestern China is also one of the world's 24 largest biodiversity hotspots (Myers et al. 2000). It is a center of Rhododendron distribution and harbors more than four hundred Rhododendron species (Fang 1999; He et al. 1994; Lu et al. 2015). Many of the Rhododendron species distributed in alpine areas extend their range above the tree-line and are long-lived with arboreal features, making them an ideal case study for the examination of long-term biological responses to climate change ( $\mathrm{Li}$ et al. 2013; Liang and Eckstein 2009; Lu et al. 2015; Tardif et al. 2001). In this paper, we: (1) investigate the effects of local climate on the radial growth of alpine shrubs; (2) reconstruct the variation in MWT during recent centuries; and (3) examine whether large-scale climatic drivers such as the El NiñoSouthern Oscillation (ENSO) and North Atlantic Oscillation (NAO) influence shrub radial growth through their effects on local climate.

\section{Materials and methods}

\subsection{Study area and climate}

The sampling sites (Fig. 1) were located in Southwestern China, at the geographical junction between the YunnanGuizhou and Tibetan plateaus. This area is situated at the meeting point of the Southeastern and Southwestern Asian monsoon branches in summer (Bohner 2006) and is affected by the East Asian winter monsoon in winter $\mathrm{Hu}$ et al. 2015). The region's climate (Fig. 2) is characterized by distinct dry (October to April) and rainy seasons (May to September). The vegetation zones occur along an elevation gradient. At the tree-line zone, Abies forestii var. georgei is the dominant species in the over-story and canopy, and Rhododendron mainly comprises the understory (Liu 2004). 
Fig. 1 Location of study area in China (a) and locations of tree-ring sampling sites and the meteorological stations in the study area (b)

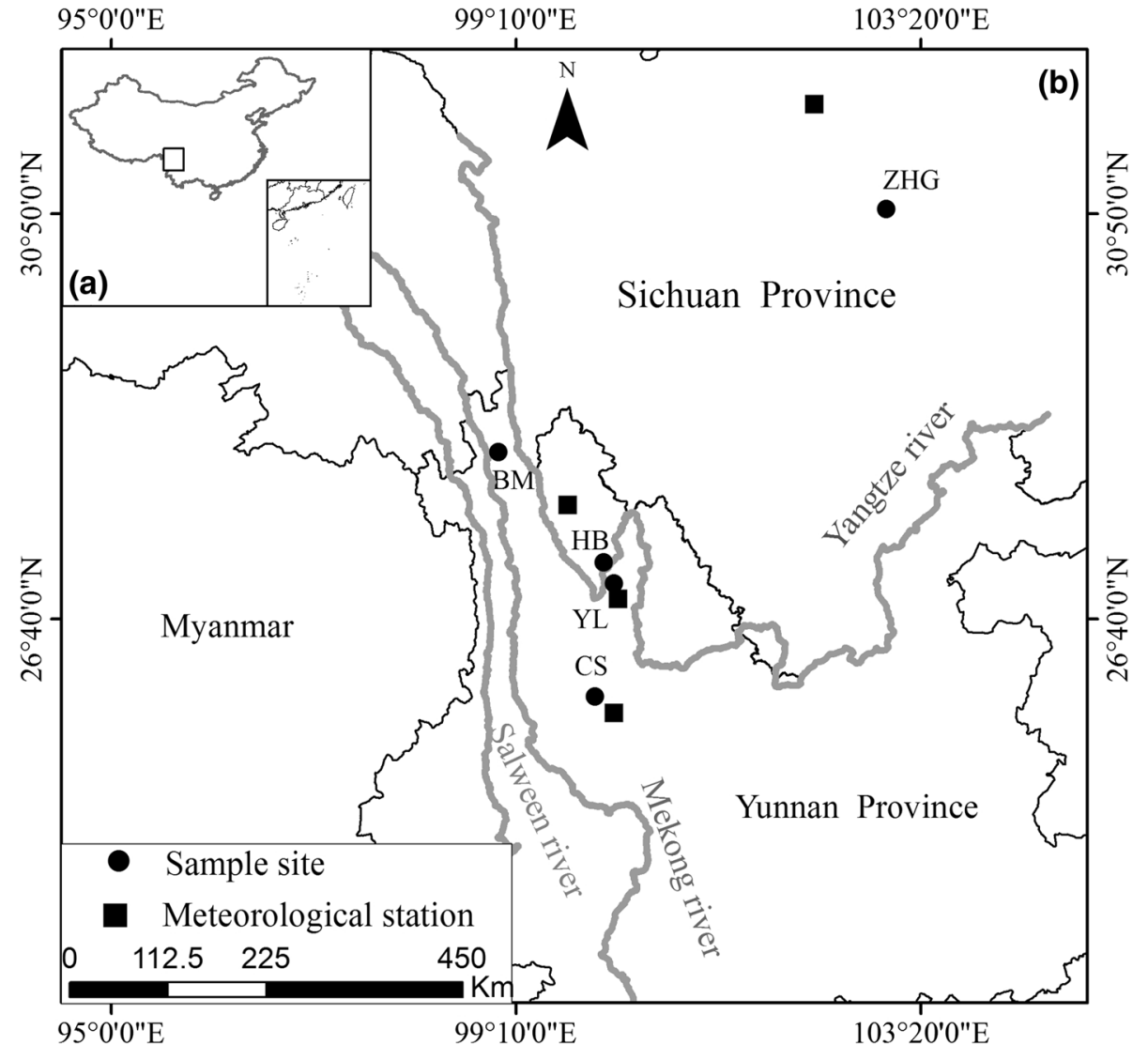

\subsection{Tree-ring sampling}

Shrub tree-ring samples were collected from above the tree-line at five sites (Table 1; Fig. 1), in areas relatively undisturbed by human activities. Four sites were located in Yunnan Province: Baima Snow Mountain (BM), Haba Snow Mountain (HB), Cangshan Mountain (CS) and Yulong Mountain (YL); a further site, Zhegu Mountain (ZHG), was located in Sichuan Province. Four species were sampled: $R$. phaeochrysum, $R$. traillianum, $R$. przewalskii and $R$. alutaceum (see Table 2 for detailed species information). To obtain high quality tree-ring data, only those Rhododendron individuals free from obvious disease and with erect trunks were selected. Each stem was harvested at approximately $40 \mathrm{~cm}$ above the root collar of each sample plant. In total, 30/30/19/30/60 stem discs were collected at the $\mathrm{BM} / \mathrm{HB} / \mathrm{ZHG} / \mathrm{CS} / \mathrm{YL}$ sites, respectively. The heights of the sampled individuals ranged from 2 meters to 5 meters.

After air drying, the discs were polished using a grinding machine with 50 to 100 -grit sandpaper. They were then hand polished using 300,600, 800 and 1200-grit sandpaper in sequence. Ring widths were registered using a LINTAB (Lintab System, Rinntech, Germany) measurement system with a resolution of $0.01 \mathrm{~mm}$. Each disc was measured twice in two directions using an angle greater than $60^{\circ}$.
All tree-ring series were cross-dated visually and statistically tested using COFECHA software (Holmes 1983). Series with poor quality, in which the tree rings were rotten or broken, or that correlated weakly with the master chronology were discarded from further analyses. In total, $44 / 36 / 38 / 40 / 82$ series from 22/18/19/20/41 discs from the $\mathrm{BM} / \mathrm{HB} / \mathrm{ZHG} / \mathrm{CS} / \mathrm{YL}$ sites respectively were used. Basic information about the series is summarized in Table 1.

\subsection{Chronology development}

In order to reduce the potential heteroscedasticity found in the raw ring-width measurements, a data-adaptive power transformation was applied to raw ring-width data. In order to remove biological growth trends and retain signals of growth variation related to climate variability, it was also necessary to detrend the data (Cook and Kairiūkštis 1990; Cook et al. 1994). Various detrending methods were employed, with the purpose of selecting the best fitting method and of testing the sensitivity of the results in response to the methods applied. All the detrending methods yielded similar results (Table S1 in Appendix_S1); for our final analysis, we took the result from a negative exponential function or a straight line of any slope. To reduce the influence of outliers, all detrended series were averaged 

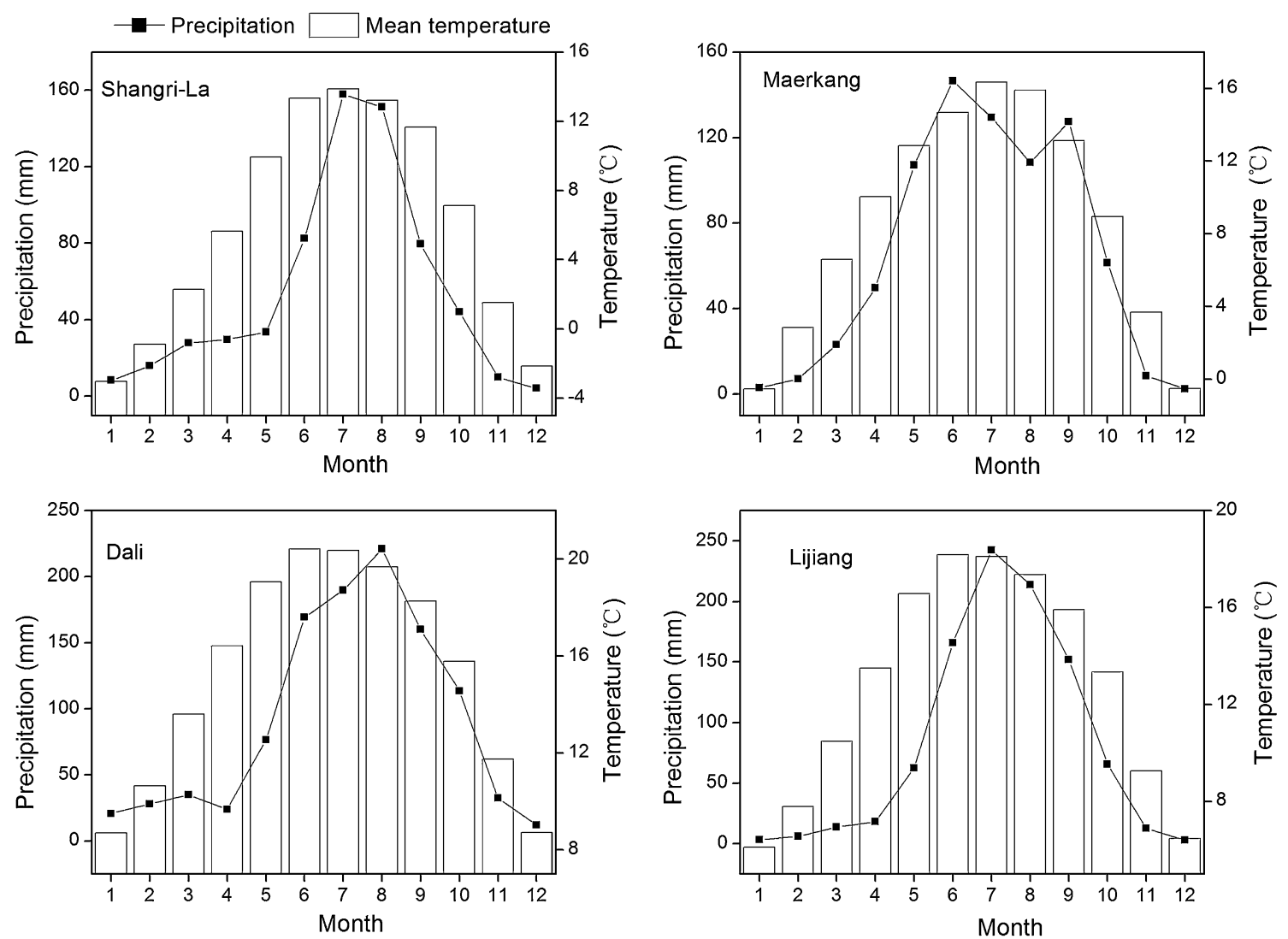

Fig. 2 Variations of monthly mean air temperature $\left({ }^{\circ} \mathrm{C}\right)$ and precipitation $(\mathrm{mm})$ recorded at representative Meteorological Stations $($ Shangri-la, Maerkang, Dali and Lijiang station) of Southwestern China

Table 1 Site information and standard Rhododendron chronology statistics

\begin{tabular}{lllllll}
\hline & BM & HB & ZHG & CS & YL & RC \\
\hline Species & R. phaeochrysum & R. traillianum & R. przewalskii & R. alutaceum & R. traillianum \\
Location Lat./Lon. & $28.38 / 99.99$ & $27.36 / 100.07$ & $30.88 / 102.98$ & $25.87 / 98.99$ & $27.03 / 100.18$ \\
Sampling elev. (m) & 4400 & 4200 & 4050 & 3310 & 4000 & - \\
Location & Tree-line & Tree-line & Tree-line & Summit & Tree-line & - \\
Stem discs & 22 & 18 & 19 & 20 & 41 & 40 \\
Time span A.D. & $1670-2011$ & $1765-2011$ & $1943-2009$ & $1920-2011$ & $1855-2011$ \\
SD & 0.20 & 0.30 & 0.32 & 0.30 & 0.31 & $1670-2011$ \\
MS & 0.15 & 0.15 & 0.14 & 0.13 & 0.2 & 0.30 \\
AC1 & 0.63 & 0.70 & 0.63 & 0.69 & 0.48 & 0.16 \\
Rbar & 0.28 & 0.37 & 0.46 & 194 & 0.32 & 0.68 \\
EPS $>0.85$ & 1815 & 1800 & 1943 & 1935 & 1870 \\
\hline
\end{tabular}

BM, Baima Snow Mountain; HB, Haba Snow Mountain; ZHG, Zhegu Mountain; CS, Cangshan Mountain; YL, Yulong Snow Mountain; RC, Regional Composite; Lat., latitude; Lon., Longitude; Elev., elevation; SD, standard deviation; MS, mean sensitivity; AC1, first-order autocorrelation; Rbar, mean inter-series correlation; EPS, expressed population signal

into the chronology by computing the bi-weight robust mean. To minimize the effect of higher standard deviations in weakly replicated portions of the chronology, such as the early part of the chronology which used a relatively small sample size, the variance of chronology was also stabilized (Osborn et al. 1997).

The strength of the chronology was assessed by the mean inter-series correlation (Rbar) and the expressed 


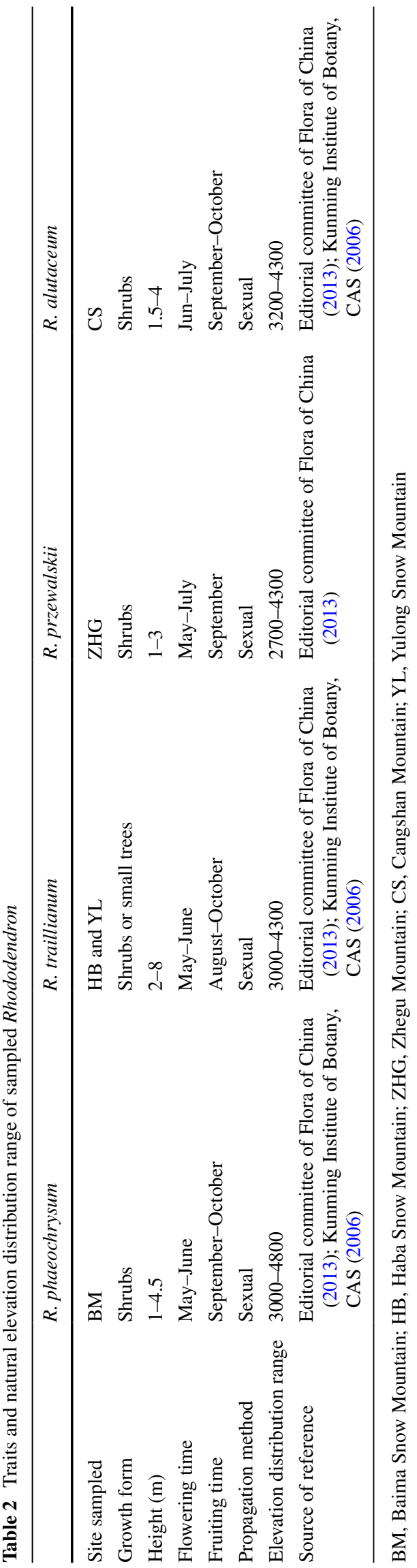

population signal (EPS). Both Rbar and EPS were calculated from 30-year moving windows with a 15-year overlap along the chronology. A chronology was considered reliable when the EPS was above the threshold of 0.85 . The reliable periods for $\mathrm{BM}, \mathrm{HB}, \mathrm{ZHG}, \mathrm{CS}$ and $\mathrm{YL}$ site chronologies were 1815-2011, 1800-2011, 1943-2009, 19352011 and 1870-2011, respectively (Table 1).

\subsection{Regional composite chronology development}

The correlations between the standard chronologies of the common period 1943-2009 at the five sites were calculated. They varied from 0.12 to 0.57 (Table 3), which indicated that they were subject to common climatic conditions. In order to develop a long and promising regional composite chronology (RC chronology), we further tested the chronology correlation during 1870-2011 between $\mathrm{BM}, \mathrm{HB}$ and YL. The highest correlation $(\mathrm{r}=0.56)$ was found between $\mathrm{BM}$ and $\mathrm{HB}$, where the raw tree-ring series were pooled for the computation of final RC chronology. The $95 \%$ confidence interval of the RC chronology was presented using the method described by Paul (1991).

\subsection{Climate data}

Instrumental meteorology devices are rarely installed above the tree-line. Data from nearby stations (installed $1.5 \mathrm{~m}$ above ground) are generally used as surrogates for constructing the relationships between tree-ring chronology and climatic variables. To test the agreement of the abovetree-line climatic variables with those of the proxy station, we used an on-site climatic observation system $\left(28.37^{\circ} \mathrm{N}\right.$, $99.99^{\circ} \mathrm{E}, 4810 \mathrm{~m}$ a.s.1, $20 \mathrm{~cm}$ above ground) installed in May 2012 at BM as a reference for verification. Correlation between the on-site monitored data with those collected from the Shangri-La Meteorological Station (situated about $94 \mathrm{~km}$ from the BM sampling site) (Fig. 2), were 0.98 for air temperature and 0.84 for air humidity. The temperature and air humidity in $\mathrm{BM}$ were $7.79{ }^{\circ} \mathrm{C}$ lower and $14.16 \%$ higher than the values recorded at Shangri-La respectively (Fig. 3). These high correlations suggested that the proxy data recorded from the Meteorological Stations was suitable for use in the final analysis. The Shangri-La Meteorological Station provided four records of temperature per day, taken at 02:00, 08:00, 12:00 and 20:00 China Time (Beijing), from which the daily average temperature, daily minimum temperature and daily maximum temperature were calculated. Monthly mean temperature, monthly mean minimum and monthly mean maximum temperature were calculated as the averaged results of daily records for the given month. This data, along with total precipitation data from 1958 to 2011, was retrieved from the China Meteorological Data Sharing Service System (http://cdc.cma.gov.cn/). 
Table 3 Correlation matrix between chronologies of the five treering sites for the common period 1943-2009 (and 1870-2011 for $\mathrm{BM}, \mathrm{HB}$ and $\mathrm{YL}$ )

\begin{tabular}{llllll}
\hline Site & BM & HB & ZHG & CS & YL \\
\hline BM & 1 & - & - & - & - \\
HB & $0.57(0.56)$ & 1 & - & - & - \\
ZHG & 0.12 & 0.15 & 1 & - & - \\
CS & 0.29 & 0.36 & 0.37 & 1 & - \\
YL & $0.34(0.22)$ & $0.39(0.33)$ & 0.19 & 0.23 & 1 \\
\hline
\end{tabular}

BM, Baima Snow Mountain; HB, Haba Snow Mountain; ZHG, Zhegu Mountain; CS, Cangshan Mountain; YL, Yulong Snow Mountain

\subsection{Climate-growth relationship analysis and MWT reconstruction}

The climate-growth relationship was explored using Pearson's correlation coefficients on a monthly basis, from which months with significant coefficients were identified for each climatic variable. In this study, we defined winter as the period from December to February. Therefore, MWT was computed using Eq. (1), which was defined as the average value of monthly minimum temperatures in December $\left(\operatorname{Tmin}_{D e c}\right)$, January $\left(\operatorname{Tmin}_{J a n}\right)$, and February $\left(\operatorname{Tmin}_{\mathrm{Feb}}\right)$. A linear model was employed to reconstruct the variations in MWT in Southwestern China based on the standard RC chronology of Rhododendron. The leave-one-out cross validation method (Briffa et al. 1988) was performed to validate the results of the reconstruction. Statistics such as Pearson's correlation coefficients $(r)$, variance explained $\left(R^{2}\right)$, reduction of error statistics $(R E)$ were also evaluated (Fritts 1976).

$M W T=\left(\operatorname{Tmin}_{D e c}+\operatorname{Tmin}_{J a n}+\operatorname{Tmin}_{F e b}\right) / 3$

\subsection{Spatial correlation and spectrum analysis}

To investigate whether our reconstruction represents regional-scale climatic variations, we correlated reconstructed data and instrumental records with the Climate Research Unit Time Series (CRU TS) 3.22 dataset (Harris et al. 2014) of all grid cells available for the defined region from 1958 to 2011 . We also wanted to to test whether a large-scale climatic driver such as ENSO influences tree growth through its effects on local climate change. In order to investigate this question, we performed spatial correlation analysis on the reconstructed data and the gridded Hadley Center sea ice and sea surface temperature (SST) dataset version 1 (Rayner et al. 2003) from 1950 to 2011. The analyses were performed using on-line tools developed by the Royal Netherlands Meteorological Institute (KNMI) climate explorer (http://climexp.knki.nl). In addition, we correlated the reconstructed data with the NAO index, which was downloaded from the Climate Prediction Center (http://www.cpc.noaa.gov/data/teledoc/telecontents. shtml) to evaluate whether tree growth is influenced by NAO through their effects on local MWT change. Moreover, power-spectrum analysis was used to evaluate the

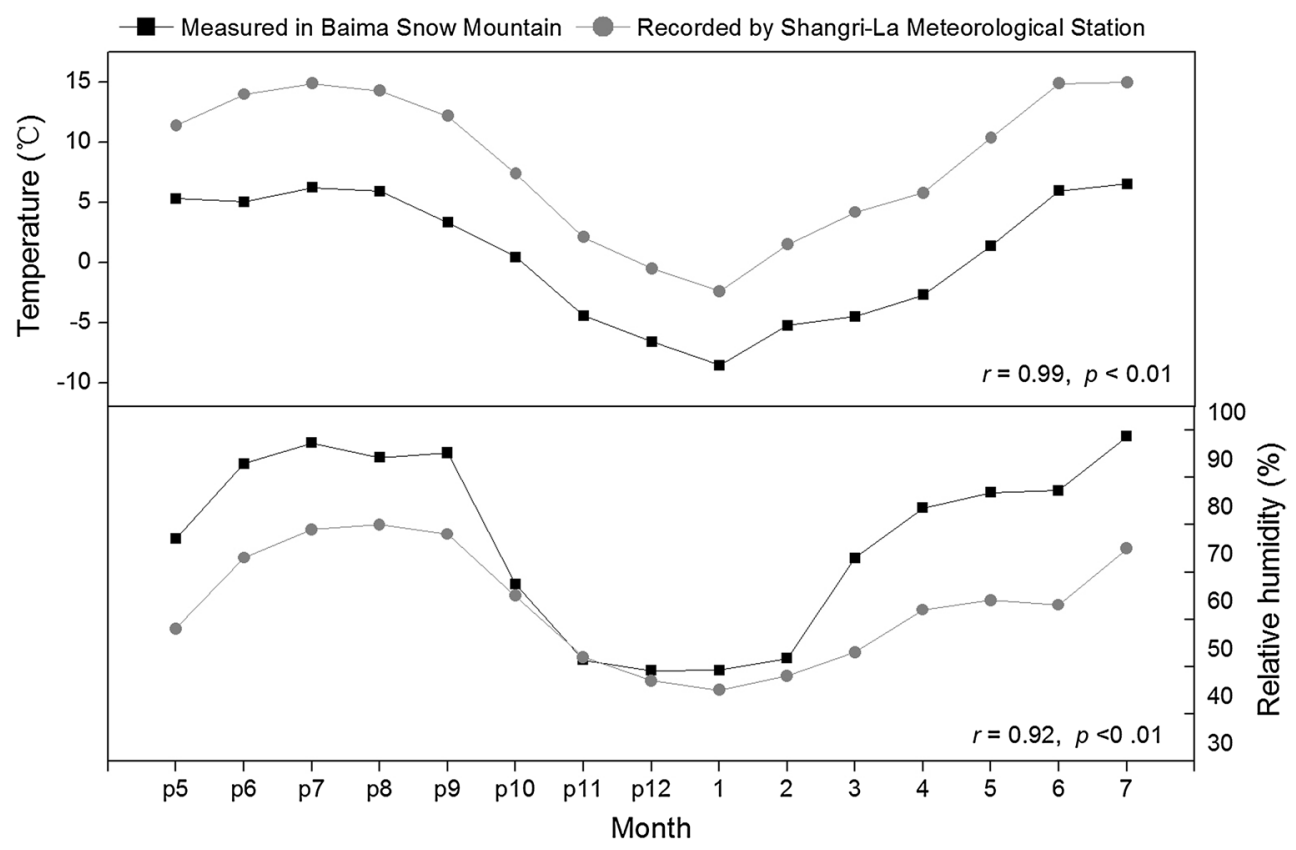

Fig. 3 Variations of monthly mean air temperature $\left({ }^{\circ} \mathrm{C}\right)$ and air humidity $(\%)$ recorded at the Shangri-La Meteorological Station and at the onsite climatic observation system in the BM from May 2012 to July 2013. p on the horizontal axis refers to month in the preceding year 
Fig. 4 The standard RC chronology and its signal strength statistics, a standard RC chronology with its $95 \%$ confidence level, b running expressed population signal (dotted line is 0.85), c sample depth. The vertical dotted line demarks the start of the reliable reconstruction

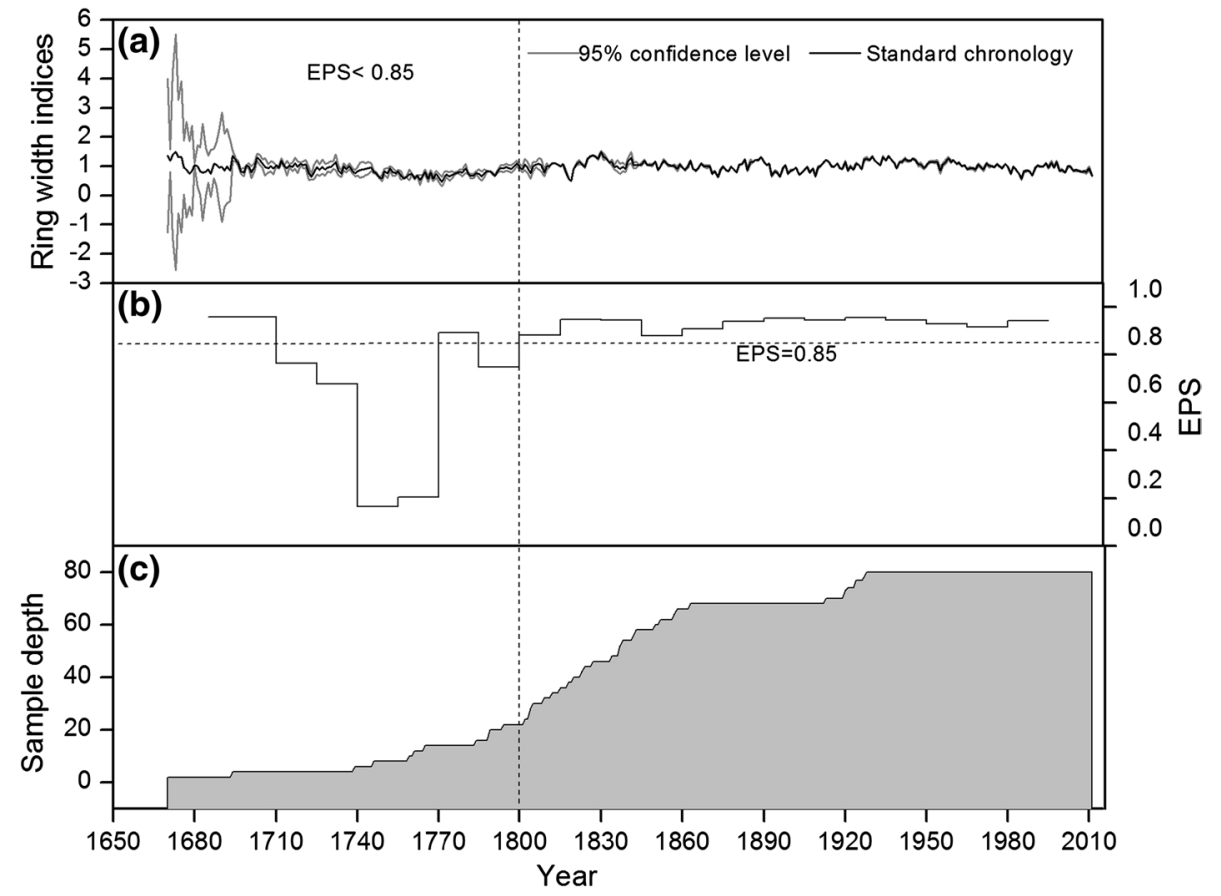

frequency domains of the reconstructed MWT (Fan et al. 2008). In order to validate the reconstruction, it was further compared with other related temperature series from nearby regions.

\section{Results}

\subsection{Chronology statistics}

Descriptive statistics of the standard site chronologies and RC chronology are illustrated in Table 1. The mean sensitivity (MS) was 0.16 , indicating that our chronology showed a low level of annual variation, which is similar to results from other studies (Liang and Eckstein 2009; Lu et al. 2015). The Rbar is 0.24 and EPS exceeds the recommended threshold of 0.85 after year 1800 (Fig. 4), which indicates that the chronology is suitable for the study of climate-growth relationships. Although our data extended to 1670 , the $95 \%$ confidence intervals (Fig. 4) and EPS suggest that the low-frequency variation in the RC chronology is reliable only after the year 1800 . Therefore, we selected 1800 (replicated with 22 series) as the starting year for regional climate reconstruction. The final length of the $\mathrm{RC}$ is 211 years, enabling it to capture centennial, multidecadal and decadal climatic variation.

\subsection{Growth response to climate variables}

Figure 5 shows the correlation coefficients between the standard RC chronology and monthly mean, maximum and minimum temperatures, relative humidity, pan evaporation and total precipitation. In general, the standard RC chronology is negatively correlated with temperature, excluding the maximum temperature in the previous October, April and July. It positively correlates with relatively humidity in most months, but negatively correlates with pan evaporation all year around. In most of the cases, precipitation negatively correlates with RC chronology, except for March, August and the previous August and September. Among all the correlations, the MWT (minimum winter temperature) from the previous December to the current February had the highest coefficient $(r=-0.63, p<0.01$, Fig. 5) with the standard RC chronology. We therefore used the standard RC chronology as a predictor to reconstruct the MWT in Southwest China.

\subsection{MWT reconstruction}

A linear model $(\mathrm{MWT}=-6.84 \times \mathrm{RC}-0.22, r=-0.63$, $p<0.01)$ was developed to reconstruct the variations of MWT based on the RC chronology since the year 1800 . The regression model accounts for $40 \%$ of variance over the calibration period from 1958 to 2011 (Table 4). The leave-one-out cross validation test produced a positive $\mathrm{RE}$, indicating good accuracy of the developed regression model. A significance test, product mean test and correlation coefficient between recorded data and estimated data from the leave-one-out method demonstrated that the developed reconstruction model was reliable.

We calibrated and verified the model and reconstructed the MWT (Fig. 6) using the whole length of the 

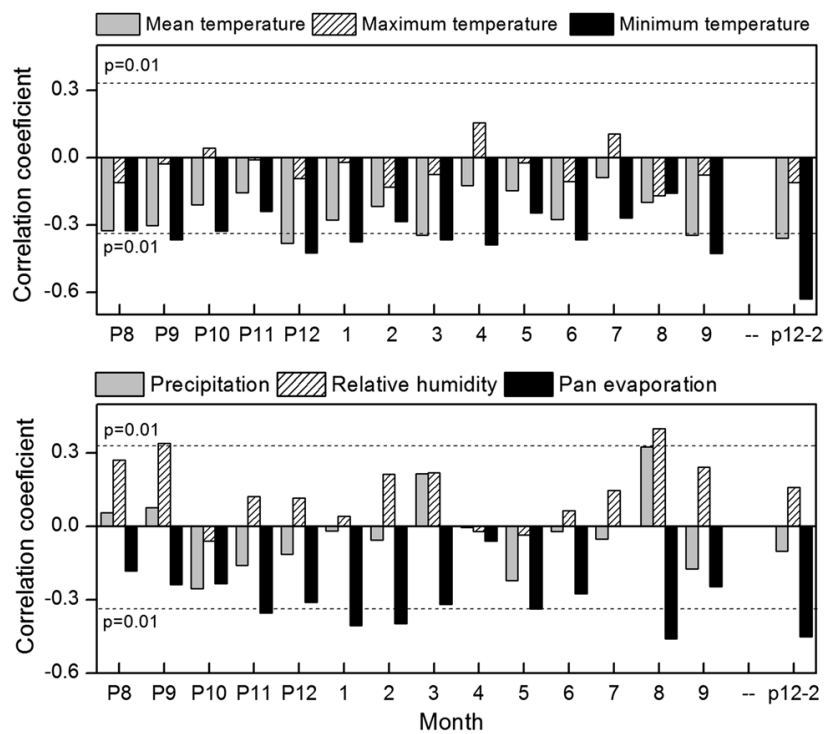

Fig. 5 Correlation coefficients between climatic variables (monthly maximum and minimum temperature, mean monthly temperature, total precipitation, monthly pan evaporation and relative humidity) with the standard $\mathrm{RC}$ chronology. $\mathrm{P}$ on the horizontal axis refers to month in the preceding year

RC chronology. However, only the results after year 1800 , when the reliable chronology begins, were interpreted. The mean and standard deviation of the reconstructed MWT were -10.3 and $1.31{ }^{\circ} \mathrm{C}$ over the reliable period. The reconstructed MWT series of the past 211 years shows a multidecadal fluctuation interweaving with cooling and warming periods. Four warm and three cold periods were identified, based on their deviations from the overall mean MWT value $\left(-10.3^{\circ} \mathrm{C}\right)$. Warm periods with MWT values greater than $-10.3{ }^{\circ} \mathrm{C}$ prevailed during $1800-1822$, 18581881, 1892-1921 and 1966-2011; while cold periods with MWT values less than $-10.3{ }^{\circ} \mathrm{C}$ occurred in $1823-1858$, 1882-1891 and 1922-1965. The most recent eight decades (1930-2011) experienced a continuous increase of MWT when the value changed from $-13.04{ }^{\circ} \mathrm{C}$ in 1930 to $-8.14{ }^{\circ} \mathrm{C}$ in 2011 , which is in accordance with instrumental observation. However, the magnitude and the rate of warming are within the fluctuation range of the past two to three centuries. Power spectrum analysis reveals that high frequency peaks occurred at 2.01, 2.79, 3.20, 3.24 and
3.28 years, while significant low frequency peaks occurred at 94 and 141 years (Fig. 7).

\section{Discussion}

\subsection{Negative correlation between ring-width and MWT}

Some studies have found positive correlations between tree-ring width and winter temperature in tree-line sites. Winter temperatures promote the growth of Quercus prinus, Chamaecyparis thyoides, Pinus rigida, Q. alba, $Q$. rubra and Carya glabra at their northern range margin in North America (Pederson et al. 2004), and Betula papyrifera, Picea mariana and P. banksiana in the eastern Canadian boreal forest (Huang et al. 2010). More evidence of this positive relationship between tree ring-width and winter temperature was also found from many species in various places, such as Abies chensiensis in Sichuan Province, China (Song et al. 2007), A. spectabilus, Picea smithiana, Pinus wallichiana, Tsuga dumosa and Ulmus wallichiana in Nepal (Cook et al. 2003), Pinus massiniana in Fujian Province, China (Chen et al. 2012), Pinus armandii (Shi et al. 2009) and Pinus tabulaeformis in the Northwestern Tibetan Autonomous Region, China (Liu et al. 2009), Juniperus przewalskii in the Northeastern Tibetan Autonomous Region, China (Gou et al. 2007) and A. alba in Romania (Popa and Cheval 2007). Recently, studies have also examined shrubs in the Himalayan and arctic regions. For example, $R$. aganniphum in the southeast Tibetan Autonomous Region, China (Lu et al. 2015), Cassiope fastigiata in the southeast Tibetan Autonomous Region, China and Nepal (Liang et al. 2015), and B. nana in western Greenland (Hollesen et al. 2015) were also positively correlated with winter temperature.

In the present study, however, we found a consistent negative correlation between Rhododendron ring-width and winter temperature from four species distributed over five sites (Fig. 5; Table S2-4 in Appendix_S2). Similar results were also reported from other places, including studies of T. dumosa and A. georgei in northwestern Yunnan Province, China ( $\mathrm{Li}$ et al. 2010), B. ermanii in Japan (Takahashi et al. 2005), Larix olgensis (Chen et al. 2011) and B. ermanii (Wang et al. 2012) in Jilin Province, China, Schima
Table 4 Leave-one-out cross validation statistics for the reconstruction model

\begin{tabular}{lrllllll}
\hline & $r$ & $R^{2}$ & $R_{a d j}^{2}$ & $R E$ & $S T$ & $P M T$ & $D W$ \\
\hline Calibration & $-0.63^{*}$ & $0.40^{*}$ & $0.38^{*}$ & - & - & - & - \\
Verification & $0.58^{*}$ & $0.34^{*}$ & $0.32 *$ & $0.34^{*}$ & $39+/ 14-*$ & $4.60^{*}$ & 1.10 \\
\hline
\end{tabular}

$r$, correlation coefficient; $R^{2}$, explained variance; $R_{\text {adj }}^{2}$, adjustment explained variance; RE, reduction of error statistic; ST, significant test; PMT, product mean test; DW, Durbin-Watson test

* Significant at $p<0.05$ 


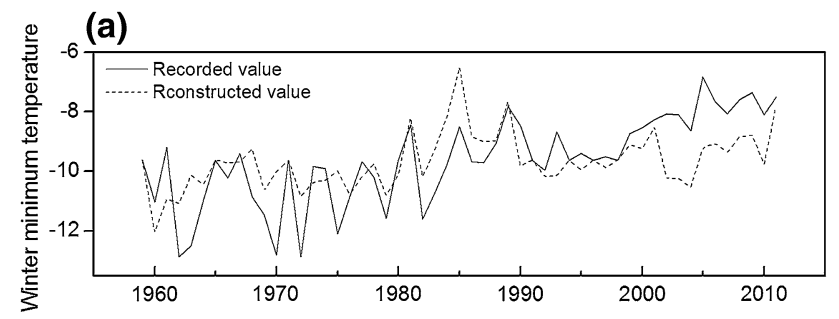

(b)

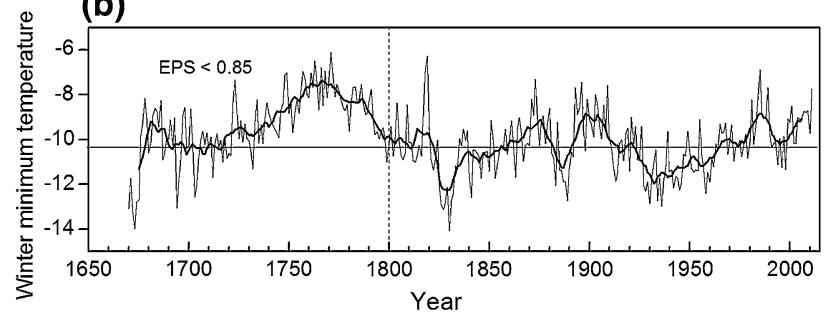

Fig. 6 Reconstructed minimum winter temperatures (WMT) (December-February) in Southwest China, a comparison of recorded values vs reconstructed values from 1958 to 2011, b reconstructed WMT over the past 211 years. The thin and thick lines represent the annual average temperature and the 11-year smoothing average temperature, respectively

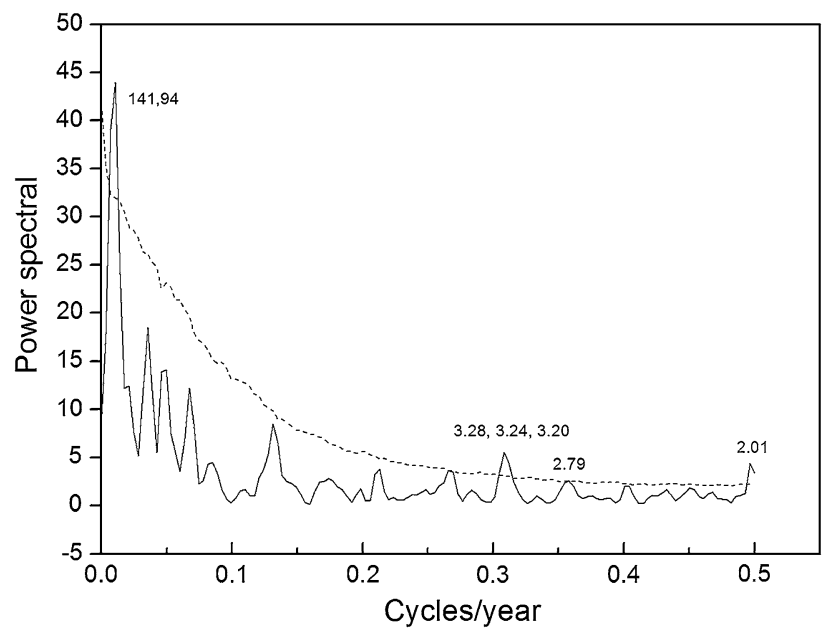

Fig. 7 Power spectral of reconstructed minimum winter temperatures (WMT); the dotted line indicates significance at $p<0.05$. The numbers in the figure represent the values of frequency peaks

superba and $P$. massoniana in Zhejiang Province, China (Su et al. 2015), Toona ciliate in Thailand (Vlam et al. 2014), P. tabulaeformis in Gansu Province, China (Fang et al. 2010a; Lu et al. 2016) and Ningxia Hui Autonomous Region and Inner Mongolia, China (Cai and Liu 2007), and B. utilis in Nepal (Bhattacharyya et al. 2006). The negative correlation found in the present and other studies has not aroused much attention, but reflects an alternative response pattern of plants to winter temperature.
Previous studies have proposed a possible explanation for this negative correlation between ring-width and winter temperatures: increasing winter temperatures could directly enhance the metabolic rate (such as respiration) of a plant (Irwin and Lee 2003). As a result, energy is consumed that would otherwise have been reserved for the later growth of the plant (Chen et al. 2011; Su et al. 2015; Vlam et al. 2014; Wang et al. 2012). Generally the minimum temperature required for net photosynthesis lies between -2 and $-5{ }^{\circ} \mathrm{C}$, while for respiration, it can be as low as $-12{ }^{\circ} \mathrm{C}$ (Meyer et al. 1973). In our study area, the mean temperature during December to February is generally below $-5{ }^{\circ} \mathrm{C}$, with an average value of $-10.3{ }^{\circ} \mathrm{C}$ (Fig. 3), thus indicating that Rhododendron respiration could be still active while photosynthesis has been shut down by low temperatures.

Other possible explanations for the negative correlation between ring-width and winter temperatures also need to be considered. In particular, for cold tolerant species such as Rhododendron, an increase in winter temperature will exert detrimental effects on its post-winter growth (Caroline et al. 2015). This may be related to three potential processes. First, plants living in temperate and alpine conditions require low winter temperatures in order to come out of their dormant winter period and continue their remaining lifecycle. Higher winter temperatures could interfere with this process and eventually have detrimental effects on the growth of the plant in the following season (Luedeling et al. 2011). Second, high winter temperature reduces and/or results in more shallow snow cover, and may subsequently cause tissue damage, physiological drought and water-transporting problems for both the above snow cover and under snow cover parts of the plant. All our sampling sites were at high elevation and subject to long term snow cover during winter (Table S5 in Appendix_S3). Snow cover provides protection for the plant, and a reduction in snow cover caused by increasing temperatures alters freeze-thaw cycles and increases the frequency and intensity of the freeze-thaw process (Caroline et al. 2015). This will increase the exposure of plants to cold events and consequently cause damage to root systems (Bokhorst et al. 2011), increasing the risk of xylem embolism (Mayr et al. 2003), and lysis of soil microbes (Groffman et al. 2001). As a consequence, the affected plant may be hypersensitive to drought and heat stress, and susceptible to pathogens and insect infestation in the following season (Auclair et al. 1996). Moreover, as suggested by Mayr et al.'s (2012) study in the Central Alps, vertical and horizontal water transportation becomes blocked when plants are frozen in winter. Under such circumstances, the plant part above snow cover is more sensitive to changes in ambient air temperature and wind than the part below snow cover. 
Higher winter temperatures cause overheating and thus a higher transpiration force, leading to dehydration of the plant part above snow cover (Mayr et al. 2012). Our studied Rhododendron species were evergreen tall shrubs with heights of 2-5 m. The parts of the plants above snow cover may suffer dehydration to a greater extent during warmer winters. Third, a warm winter brings early snow melt and allows water loss prior to the growing season, thus potentially resulting in a water shortage during the early growing season (Barbeito et al. 2012). In our study area, the growth status of the vegetation is heavily dependent on water availability during the early growing season before the arrival of the monsoon (Bi et al. 2015; Fan et al. 2009; Fang et al. 2010b; Guo et al. 2009; Sano et al. 2005, 2009; Singh et al. 2009). Further physiological research combined with field experiments will be required to conclusively identify the causal mechanisms at play. Identifying and understanding the causes of variability in the responses of different species to the same climatic conditions, whether they are biologically dependent (i.e. differences in life form and phylogeny) or environmentally determined, deserves detailed research that is beyond the scope of the present paper.

\subsection{Comparison of reconstructed MWT with other records}

The present study presents a 341-year chronology and a 211-year MWT reconstruction based on shrub-ring data from Rhododendron, starting in the year 1800 above the tree-line in Southwest China. Comparing our reconstructed MWT with other tree-ring based temperature reconstructions in nearby regions detected a level of consistency in the data (Fig. 9). Three cold periods were detected in our reconstruction, i.e. 1823-1858, 1882-1891 and 19221965. This finding generally agrees with that of temperature series reconstructed elsewhere in China in the Xizang Autonomous Region (Gou et al. 2007; He et al. 2014) and Sichuan Province (Song et al. 2007) (Fig. 8). Long, cold periods that extended from 1823 to 1858 and from 1922 to 1965 are also evident in tree-ring based winter temperature reconstructions in Nepal (Cook et al. 2003), Xinjiang Autonomous Region in China (Yuan and Li 1999) and the northern hemisphere and Arctic region (Jacoby and Darrigo 1989). These periods also overlap with historical extreme cold winter events from 1800 to 1890 and from 1900 to 1950 in Southern China (Hao et al. 2011). Distinct warm periods extended from 1892 to 1921. This corresponds to a temperature reconstruction from Guliya ice core on the Tibetan plateau from 1880 to 1989 (Yao et al. 1996), a lake sediment core in Qinghai lake of Qinghai Province, China from 1880 to 1910 (Shen et al. 2001), of Taro Co lake in Tibet Autonomous Region from 1890 to 1919 (Zhang et al. 2012), and to dendrochronological data from Nepal (Cook et al. 2003). The warm periods of $1800-1822$ and 1858 1881 were also captured by other tree-ring based temperature reconstructions in Sichuan Province, China (Song et al. 2007). It should be noted that the warming trend during the past 78 years (1933-2011) was not the warmest period in the past 211 years (Fig. 6). Similar phenomena have also been reported from central Tibet Autonomous Region in China (He et al. 2014) and Nepal (Cook et al. 2003; Sano et al. 2005). This indicates that recent warming events are within the range of long-term temperature fluctuations.

A comparison of the spatial correlations of instrumental data (Fig. 9a) and our reconstructed MWT (Fig. 9b) with the gridded MWT dataset of CRU TS 3.22 during the period of 1958-2011 shows general agreement, indicating that our reconstruction is reliable. This comparison also suggests that the MWT of Southwest China is spatially coherent with the Eastern and Central Himalaya, Southwestern and Northern China, Northern Myanmar and the Indian Peninsula (Fig. 9b).

\subsection{Teleconnections of the reconstructed MWT with large scale climate oscillations}

The high frequency peak, ranging from 2.01 to 3.28 years, falls within the variability of large scale oscillations including the NAO and the ENSO (Allan et al. 1996; Cook et al. 2002; Esper et al. 2002; Glueck and Stockton 2001), suggesting possible tele-connections between the reconstructed MWT in the Southwestern China and NAO and ENSO events. The positive correlation $(r=0.28, p<0.05$, 1950-2011) between the reconstructed MWT and winter NAO index provides further evidence of this type of teleconnection. Compared with EI Niño and La Niña events since the year 1800 (Gergis and Fowler 2009), $48 \%$ of EI Niño years corresponded to warm winters, while $52 \%$ EI Niño years corresponded to cold winters. Similarly, $53 \%$ of La Niña years corresponded to warm winters, while $47 \%$ corresponded to cold winters. This suggests that there is almost the same chance of warm and cold winters occurring in an EI Niño or an La Niña year, which implies that the reconstructed MWT is independent from ENSO events. Weak correlations were found between the reconstructed MWT with the gridded SST dataset of Hadley Center sea ice and SST dataset version 1 (Rayner et al. 2003) in Niño regions for the period of 1950-2011 (Fig. 9c). By contrast, significant positive correlations were found for the Western and part of the Central and Southern Pacific Ocean, the Northern and Southern Indian Ocean, and the Southern and part of the Northeastern Atlantic Ocean (Fig. 9c). Of these, the SST in the Western Pacific and the Northern Indian Ocean and NAO most likely affect the winter temperature of the southwestern China (Chen et al. 2009, 2012). The link between MWT in Southwest China and 


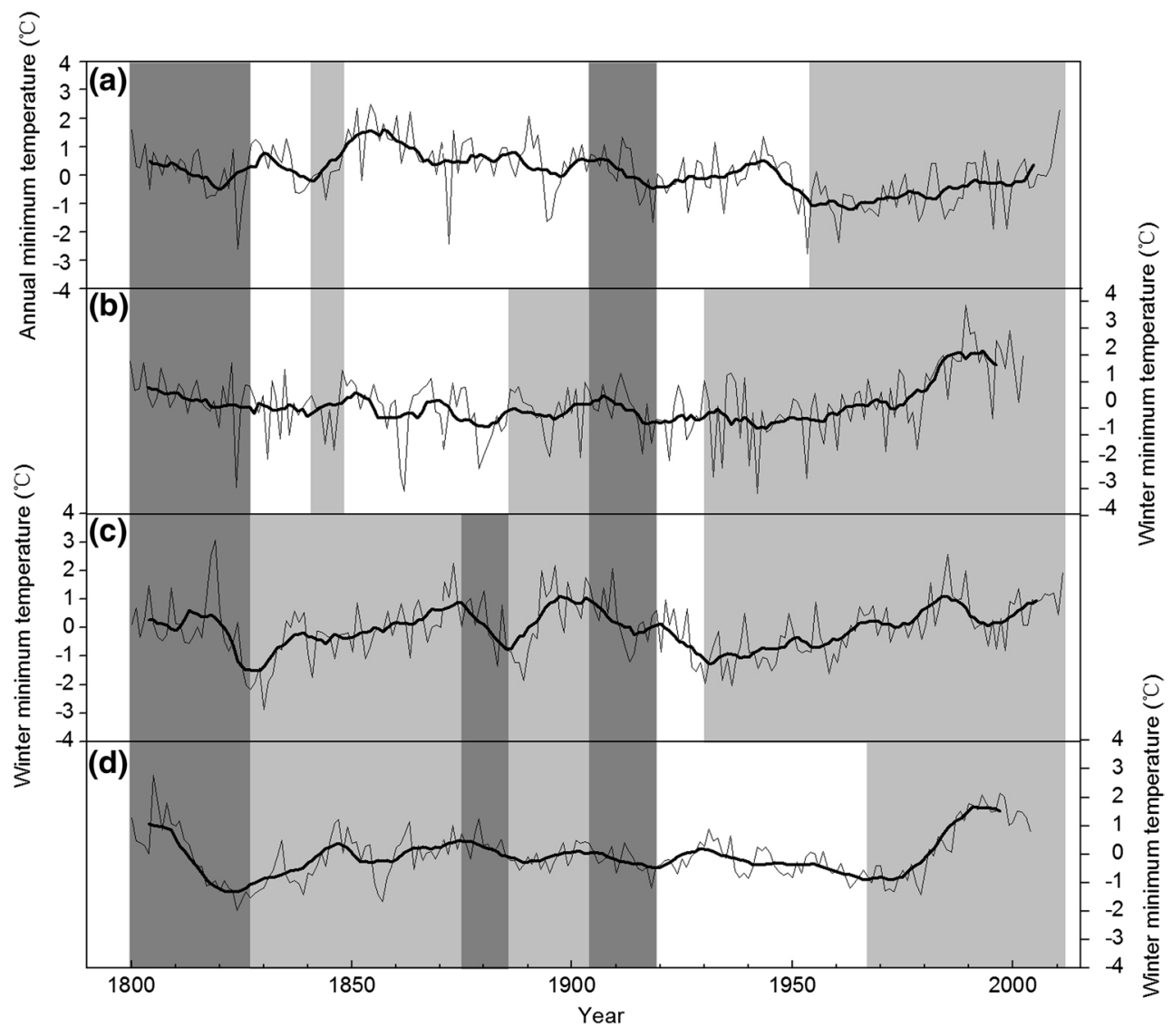

Fig. 8 Comparison between our reconstructed minimum winter temperature (WMT) and other tree-ring based temperature reconstructions in those of the surrounding regions. a reconstructed minimum temperature (from January to December) in central Tibet Autonomous Region using tree-ring width of Juniperus tibetica (He et al. 2014), b reconstructed minimum winter temperature (from previous October to March) in Northeastern Tibet Autonomous Region using tree-ring width of Juniperus przewalskii (Gou et al. 2007), c reconstructed minimum winter temperature (from previous December to February) using tree-ring width of Rhododendron in Southwest China

SST in the Western Pacific and the Northern Indian Ocean is likely due to the fact that during winter, weather conditions in China are mainly affected by the East Asian winter monsoon (Hu et al. 2015), which is mainly driven by the large thermal contrast between Eurasia and the Indo-Pacific Oceans (Chang et al. 2006; Ding 1994). Thus, higher SSTs in the Western Pacific and Northern Indian Oceans weaken the East Asian winter monsoon (Liu et al. 2008; Zhang et al. 2013), causing higher winter temperatures in China (Hu et al. 2015). As for the effect of NAO, when it is in its "positive" phase, the strengthening of Icelandic low pressure results in a larger wintertime meridional pressure gradient over the North Atlantic Ocean, which restrains the southward intrusion of the subpolar jet streams and highlatitude cold air mass, and eventually gives rise to a warm winter in Eurasia (Bridgman and Oliver 2006). (present study), d reconstructed minimum winter temperature (from previous November to March) in Sichuan Province using tree-ring width of Abies chensiensis (Song et al. 2007). All the reconstructed temperature series have been standardized using the Z-score method during the common period 1800-2011. The thin and thick lines represent the annual average temperature and an 11-year smoothing average temperature, respectively. Shaded areas show the trend consistency of reconstructed temperature from different studies, dark-grey and light-grey shaded areas represent the periods with cooling and warming trends, respectively

\subsection{Implications and outlook}

This study evaluated variation in MWTs over the past 211 years and provided essential information for understanding long-term patterns in climate change in Southwestern China, which could aid efforts at mitigating and managing climate risk. The results of this study could also provide useful supplementary information and validation data for use in global climate models. Although this region has, over the past eight decades, experienced a trend of continuous warming, this is not the warmest period that has occurred in the past two centuries (Fig. 6). However, MWT is expected to reach $-6.8{ }^{\circ} \mathrm{C}$ (average value of all scenarios and models) by the $2050 \mathrm{~s}$ and $-6.3{ }^{\circ} \mathrm{C}$ by the $2070 \mathrm{~s}$ under representative concentration pathways $2.6-8.5$ scenarios (Meehl and Bony 2011). All projections from these 
(a)

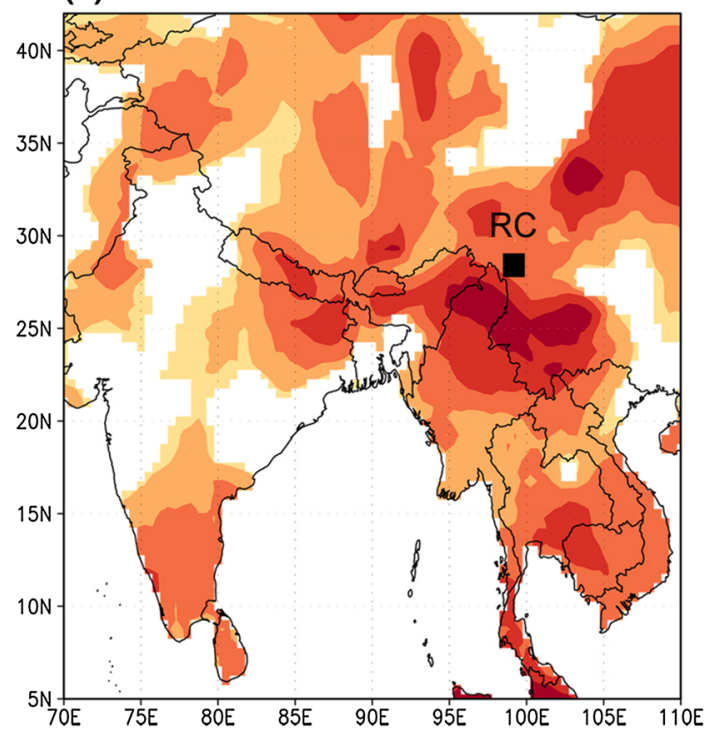

(b)

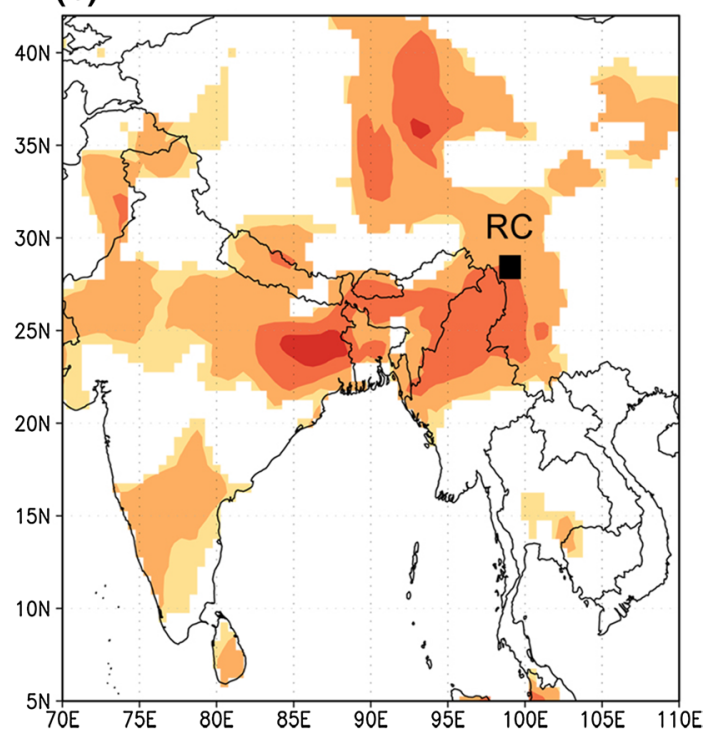

(c)
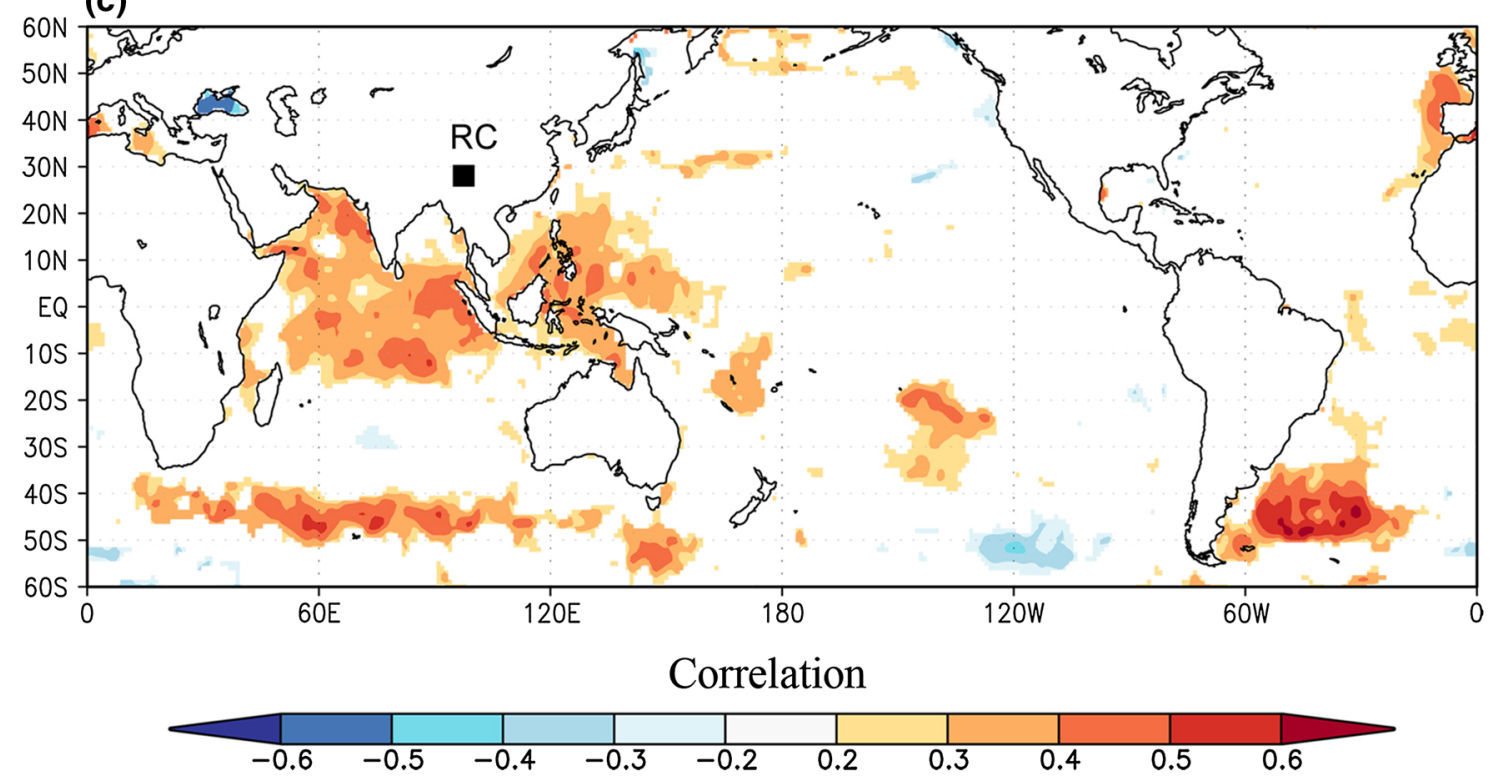

Fig. 9 Spatial correlations of the instrumental (a) and reconstructed (b) minimum winter temperature for Southwest China with the CRU TS 3.22 gridded minimum winter temperature dataset during the

scenarios and models indicate a continually increasing MWT that will exceed the highest values experienced over the past two centuries. This immense change will definitely have major effects on both ecosystems and human livelihoods in the region.

The paper also provides new findings on the response of woody shrub species above the tree-line to changes in climate. These shrub species live in the alpine transition zone, and are distributed along the continuum interface between woody tree and herb species. This continuum interface is an important ecosystem that provides unique perspectives period 1958-2011. c Spatial correlation patterns of the minimum winter temperature reconstruction with the gridded dataset of December-February Sea surface temperature for the period 1950-2011

on the distribution of various species of plants across vertical environmental gradients. Many mechanisms have been proposed to explain the limits of the distribution of woody tree species near the tree-line (Körner 2012); however, less attention has been paid to woody shrubs. This paper explicitly describes how variation in climate influences the growth of woody shrub species in areas above the tree-line. Temperature increases will be detrimental to the growth of Rhododendron species under the future climate scenarios; these species will most probably become less dominant. Their range may shrink or shift upwards as 
they seek habitat with appropriate climatic conditions. Otherwise, they will have to develop physiological and ecological strategies to cope with the increasing temperature. These changes will eventually affect the community structure and species composition of the areas above the treeline. To better understand these changes and their underlying processes, we suggest that research related to alpine woody shrubs should focus with renewed intensity on their response to climate and the consequential effects of climate change on related ecosystems.

Acknowledgments The authors gratefully acknowledge the support of the Independent Research Program of the Chinese Academy of Sciences (Grant No. KSCX2-EW-J-24), the National Natural Science Foundation of China (Grant No.31370513 and 31270524), and Southeast Asia Biodiversity Research Institute, Chinese Academy of Sciences (2015CASEABRIRG001). We also thank the Institute of Tibetan Plateau Research, Chinese Academy of Sciences, for providing a platform for tree-ring measurements, and Andrew Stevenson and Tyler Gibson for English editing.

Open Access This article is distributed under the terms of the Creative Commons Attribution 4.0 International License (http://creativecommons.org/licenses/by/4.0/), which permits unrestricted use, distribution, and reproduction in any medium, provided you give appropriate credit to the original author(s) and the source, provide a link to the Creative Commons license, and indicate if changes were made.

\section{References}

Allan R, Lindesay J, Parker D (1996) El Nino: southern oscillation and climatic variability. CSIRO Publishing, Collinwood

Auclair AN, Lill JT, Revenga C (1996) The role of climate variability and global warming in the dieback of Northern Hardwoods. Water Air Soil Pollut 91:163-186

Barbeito I, Dawes MA, Rixen C, Senn J, Bebi P (2012) Factors driving mortality and growth at treeline: a 30 -year experiment of 92,000 conifers. Ecology 93:389-401. doi:10.1890/11-0384.1

Bhattacharyya A, Shah SK, Chaudhary V (2006) Would tree ring data of Betula utilis be potential for the analysis of Himalayan glacial fluctuations? Curr Sci Bangalore 91:754

Bi YF, Xu JC, Gebrekirstos A, Guo L, Zhao MX, Liang EY, Yang XF (2015) Assessing drought variability since 1650 AD from tree rings on the Jade Dragon Snow Mountain, southwest China. Int J Climatol 35:4057-4065. doi:10.1002/joc.4264

Bohner J (2006) General climatic controls and topoclimatic variations in Central and High Asia. Boreas 35:279-295. doi:10.1080/03009480500456073

Bokhorst S, Bjerke JW, Street LE, Callaghan TV, Phoenix GK (2011) Impacts of multiple extreme winter warming events on sub arctic heathland: phenology, reproduction, growth, and $\mathrm{CO} 2$ flux responses. Glob Change Biol 17:2817-2830. doi:10.1111/j.1365-2486.2011.02424.x

Box EO, Crumpacker DW, Hardin ED (1993) A climatic model for location of plant species in Florida, USA. J Biogeogr 20:629644. doi: $10.2307 / 2845519$

Bridgman HA, Oliver JE (2006) The global climate system: patterns, processes, and teleconnections. Cambridge University Press, New York

Briffa KR, Jones PD, Pilcher JR, Hughes MK (1988) Reconstructing summer temperatures in northern Fennoscandinavia back to AD 1700 using tree-ring data from Scots pine. Arct Alp Res 20:385-394. doi: $10.2307 / 1551336$

Cai QF, Liu Y (2007) January to August temperature variability since 1776 inferred from tree-ring width of Pinus tabulaeformis in Helan Mountain. J Geogr Sci 17:293-303. doi:10.1007/ s11442-007-0293-5

Caroline MW, Hugh ALH, Brent JS (2015) Cold truths: how winter drives responses of terrestrial organisms to climate change. Biol Rev 90:214-235. doi:10.1111/brv.12105

Chan X, Yu RC, Yuang WH, Li J (2013) Charactristics of the seasonal evolution of precipitation over the central western part of Hengduan mountains. Acta Meteorol Sin 71:643-651. doi:10.11676/ qxxb2013.054

Chang CP, Wang Z, Hendon H (2006) The Asian winter monsoon. Springer, Chichester, pp 89-127

Chen SY, Zhang YX, Xia Q, Bai DY, Zhang XF (2009) Analysis of relationship between winter air temperature in eastern china and sea surface temperature anomaly. Plateau Meteorol 28:1181-1188

Chen L, Wu SH, Pan T (2011) Variability of climate-growth relationships along an elevation gradient in the Changbai Mountain, northeastern China. Trees 25:1133-1139. doi:10.1007/ s00468-011-0588-0

Chen F, Yuan YJ, Wei WS, Yu SL, Zhang TW (2012) Tree ring-based winter temperature reconstruction for Changting, Fujian, subtropical region of Southeast China, since 1850: linkages to the Pacific Ocean. Theor Appl Climatol 109:141-151. doi:10.1007/ s00704-011-0563-0

Cook E, Kairiūkštis L (1990) Methods of dendrochronology: applications in the environmental sciences. Kluwer Academic Publishers, Dordrecht

Cook ER, Briffa KR, Jones PD (1994) Spatial regression methods in dendroclimatology: a review and comparison of two techniques. Int J Climatol 14:379-402. doi:10.1002/joc.3370140404

Cook ER, D'Arrigo RD, Mann ME (2002) A well-verified, multiproxy reconstruction of the winter North Atlantic Oscillation Index since AD 1400. J Clim 15:1754-1764. doi:10.1175/1520-0442(2002)015<1754:AWVMRO>2.0.CO;2

Cook ER, Krusic PJ, Jones PD (2003) Dendroclimatic signals in long tree-ring chronologies from the Himalayas of Nepal. Int J Climatol 23:707-732. doi:10.1002/joc.911

Cook ER, Anchukaitis KJ, Buckley BM, D'Arrigo RD, Jacoby GC, Wright WE (2010) Asian monsoon failure and megadrought during the last millennium. Science 328:486-489. doi:10.1126/ science. 1185188

Crumpacker DW, Box EO, Hardin ED (2001) Implications of climatic warming for conservation of native trees and shrubs in Florida. Conserv Biol 15:1008-1020. doi:10.1046/j.1523-1739.2001.0150041008.x

Ding YH (1994) Monsoons over China. Springer, London

Editorial committee of Flora of China (2013) Flora of China. Science Press, Beijing

Esper J, Cook ER, Schweingruber FH (2002) Low-frequency signals in long tree-ring chronologies for reconstructing past temperature variability. Science 295:2250-2253

Fan ZX, Bräuning A, Cao KF (2008) Tree-ring based drought reconstruction in the central Hengduan Mountains region (China) since AD 1655. Int J Climatol 28:1879-1887. doi:10.1002/joc.1689

Fan ZX, Bräuning A, Yang B, Cao KF (2009) Tree ring density-based summer temperature reconstruction for the central Hengduan Mountains in southern China. Glob Planet Change 65:1-11. doi:10.1016/j.gloplacha.2008.10.001

Fan ZX, Bräuning A, Thomas A, Li JB, Cao KF (2011) Spatial and temporal temperature trends on the Yunnan Plateau (Southwest China) during 1961-2004. Int J Climatol 31:2078-2090. doi:10.1002/joc. 2214 
Fang RZ (1999) Flora of China. The Scientific press, Beijing

Fang KY, Gou XH, Chen FH, D’Arrigo R, Li JB (2010a) Treering based drought reconstruction for the Guiqing Mountain (China): linkages to the Indian and Pacific Oceans. Int J Climatol 30:1137-1145

Fang KY, Gou XH, Chen FH, Li JB, D'Arrigo R, Cook ER, Yang T, Davi N (2010b) Reconstructed droughts for the southeastern Tibetan Plateau over the past 568 years and its linkages to the Pacific and Atlantic Ocean climate variability. Clim Dyn 35:577-585. doi:10.1007/s00382-009-0636-2

Fritts HC (1976) Tree rings and climate. Academic Press, London

Gergis JL, Fowler AM (2009) A history of ENSO events since AD 1525: implications for future climate change. Clim Change 92:343-387

Glueck MF, Stockton CW (2001) Reconstruction of the North Atlantic oscillation, 1429-1983. Int J Climatol 21:1453-1465

Gou XH, Chen FH, Jacoby GD, Cook E, Yang MX, Peng HF, Zhang $Y$ (2007) Rapid tree growth with respect to the last 400 years in response to climate warming, northeastern Tibetan Plateau. Int J Climatol 27:1497-1503. doi:10.1002/joc.1480

Groffman PM, Driscoll CT, Fahey TJ, Hardy JP, Fitzhugh RD, Tierney GL (2001) Colder soils in a warmer world: a snow manipulation study in a northern hardwood forest ecosystem. Biogeochemistry 56:135-150

Guo GA, Li ZS, Zhang QB, Ma KP, Mu CL (2009) Dendroclimatological studies of Picea likiangensis and Tsuga dumosa in Lijiang, China. IAWA J 30:435-441. doi:10.1163/22941932-90000230

Hallinger M, Manthey M, Wilmking M (2010) Establishing a missing link: warm summers and winter snow cover promote shrub expansion into alpine tundra in Scandinavia. New Phytol 186:890-899. doi:10.1111/j.1469-8137.2010.03223.x

Hao ZX, Zheng JY, Ge QS, Ding LL (2011) Variations of extreme cold winter events in Southern China in the past 400 years. Acta Geogr Sin 66:1479-1485

Harris I, Jones PD, Osborn TJ, Lister DH (2014) Updated high-resolution grids of monthly climatic observations-the CRU TS3. 10 Dataset. Int J Climatol 34:623-642. doi:10.1002/joc.3711

He MY, Fang MY, Hu WG, Hu LZ (1994) Flora of China. The Scientific Press, Beijing

He MH, Yang B, Datsenko NM (2014) A six hundred-year annual minimum temperature history for the central Tibetan Plateau derived from tree-ring width series. Clim Dyn 43:641-655. doi:10.1007/s00382-013-1882-x

Hollesen J, Buchwal A, Rachlewicz G, Hansen BU, Hansen MO, Stecher O, Elberling B (2015) Winter warming as an important co-driver for Betula nana growth in western Greenland during the past century. Glob Change Biol 21:2410-2423

Holmes RL (1983) Computer-assisted quality control in tree-ring dating and measurement. Tree-Ring Bull 43:69-78

Hu CD, Yang S, Wu QG (2015) An optimal index for measuring the effect of East Asian winter monsoon on China winter temperature. Clim Dyn. doi:10.1007/s00382-015-2493-5

Huang JG, Tardif JC, Bergeron Y, Denneler B, Berninger F, Girardin MP (2010) Radial growth response of four dominant boreal tree species to climate along a latitudinal gradient in the eastern Canadian boreal forest. Glob Change Biol 16:711-731

Hughes MK, Swetnam TW, Diaz HF (2010) Dendroclimatology: progress and prospects. Springer, Dordrecht

IPCC (2014) Intergovernmental panel on climate change, fifth assessment report, working group II: impacts, adaptation, and vulnerability. Cambridge University Press, Colombia

Irwin JT, Lee JRE (2003) Cold winter microenvironments conserve energy and improve overwintering survival and potential fecundity of the goldenrod gall fly, Eurosta solidaginis. Oikos 100:71-78. doi:10.1034/j.1600-0706.2003.11738.x
Jacoby GC, Darrigo R (1989) Reconstructed northern hemisphere annual temperature since 1671 based on high-latitude tree-ring data from north-America. Clim Change 14:39-59. doi:10.1007/bf00140174

Körner C (2012) Alpine treelines: functional ecology of the global high elevation tree limits. Springer, Berlin

Kreyling J (2010) Winter climate change: a critical factor for temperate vegetation performance. Ecology 91:1939-1948. doi:10.1890/09-1160.1

Kunming Institute of Botany, CAS (2006) Flora of Yunnan. Science Press, Beijing

Li ZS, Shi CM, Liu YB, Zhang JL, Zhang QB, Ma KP (2010) Winter Drought Variations Based on Tree-ring data in Gaoligong Mountain, northwestern Yunanna, China, AD 1795-2004. Pak J Bot 43:2469-2478

Li ZX, He YQ, Wang CF, Wang XF, Xin HJ, Zhang W, Cao WH (2011) Spatial and temporal trends of temperature and precipitation during 1960-2008 at the Hengduan Mountains, China. Quat Int 236:127-142. doi:10.1016/j.quaint.2010.05.017

Li ZS, Liu GH, Fu BJ, Zhang QB, Ma KP, Pederson N (2013) The growth-ring variations of alpine shrub yuprzewalskii reflect regional climate signals in the alpine environment of Miyaluo Town in Western Sichuan Province, China. Acta Ecol Sin 33:23-31. doi:10.1016/j.chnaes.2012.12.004

Liang EY, Eckstein D (2009) Dendrochronological potential of the alpine shrub Rhododendron nivale on the south-eastern Tibetan Plateau. Ann Bot 104:665-670. doi:10.1093/aob/mcp158

Liang EY, Lu XM, Ren P, Li XX, Zhu LP, Eckstein D (2012) Annual increments of juniper dwarf shrubs above the tree line on the central Tibetan Plateau: a useful climatic proxy. Ann Bot 109:721-728. doi:10.1093/aob/mcr315

Liang EY, Liu WW, Ren P, Dawadi B, Eckstein D (2015) The alpine dwarf shrub Cassiope fastigiata in the Himalayas: does it reflect site-specific climatic signals in its annual growth rings? Trees 29:79-86. doi:10.1007/s00468-014-1128-5

Liu Q (2004) The effects of gap size and within gap positionon the survival and growth of natural regenerated Abies georgei seedlings. Acta Phytoecol Sin 28:204-209

Liu XD, Yin ZY, Shao XM, Qin NS (2006) Temporal trends and variability of daily maximum and minimum, extreme temperature events, and growing season length over the eastern and central Tibetan Plateau during 1961-2003. J Geophys Res-Atmos 111:D19109. doi:10.1029/2005jd006915

Liu YY, Zhao D, Cao J (2008) A Mechanism for the impact of sea surface temperature anomaly over tropical pacific and Indian Ocean on East Asian Winter Monsoon. Plateau Mt Meteorol Res 28:24-29

Liu Y, Linderholm HW, Song HM, Cai QF, Tian QH, Sun JY, Chen DL, Simelton E, Seftigen K, Tian H, Wang RH, Bao G, An ZS (2009) Temperature variations recorded in Pinus tabulaeformis tree rings from the southern and northern slopes of the central Qinling Mountains, central China. Boreas 38:285-291. doi:10.1111/j.1502-3885.2008.00065.x

Lu XM, Camarero JJ, Wang YF, Liang EY, Eckstein D (2015) Up to 400-year-old Rhododendron shrubs on the southeastern Tibetan Plateau: prospects for shrub-based dendrochronology. Boreas. doi:10.1111/bor.12122

Lu R, Jia F, Gao S, Shang Y, Chen Y (2016) Tree-ring reconstruction of January-March minimum temperatures since 1804 on Hasi Mountain, northwestern China. J Arid Environ 127:66-73

Luedeling E, Girvetz EH, Semenov MA, Brown PH (2011) Climate change affects winter chill for temperate fruit and nut trees. PLoS One 6:e20155. doi:10.1371/journal.pone.0020155

Matsui T, Yagihashi T, Nakaya T, Taoda H, Yoshinaga S, Daimaru H, Tanaka N (2004) Probability distributions, vulnerability and sensitivity in Fagus crenata forests following 
predicted climate changes in Japan. J Veg Sci 15:605-614. doi:10.1111/j.1654-1103.2004.tb02302.x

Mayr S, Gruber A, Bauer H (2003) Repeated freeze-thaw cycles induce embolism in drought stressed conifers (Norway spruce, stone pine). Planta 217:436-441. doi:10.1007/s00425-003-0997-4

Mayr S, Schmid P, Beikircher B (2012) Plants in alpine regions: Plant water relations in alpine winter. Springer, Berlin

Meehl GA, Bony S (2011) Introduction to CMIP5. Clivar Exch $16: 2-5$

Meyer BS, Anderson DB, Bohning RH (1973) Introduction to plant physiology. Princeton, Van Nostrand

Milton SJ, Gourlay ID, Dean WRJ (1997) Shrub growth and demography in arid Karoo, South Africa: inference from wood rings. J Arid Environ 37:487-496. doi:10.1006/jare.1996.0292

Myers N, Mittermeier RA, Mittermeier CG, Da Fonseca GAB, Kent J (2000) Biodiversity hotspots for conservation priorities. Nature 403:853-858. doi:10.1038/35002501

Myers-Smith IH et al (2015) Climate sensitivity of shrub growth across the tundra biome. Nat Clim Change 5:1-5. doi:10.1038/ NCLIMATE2697

Osborn TJ, Briffa KR, Jones PD (1997) Adjusting variance for sample size in tree-ring chronologies and other regional mean timeseries. Dendrochronologia 15:89-99

Paul RS (1991) Identifying low-frequency tree-ring variation. Treering. Bulletin 51:29-38

Pederson N, Cook ER, Jacoby GC, Peteet DM, Griffin KL (2004) The influence of winter temperatures on the annual radial growth of six northern range margin tree species. Dendrochronologia 22:7-29

Popa I, Cheval S (2007) Early winter temperature reconstruction of Sinaia area (Romania) derived from tree-rings of silver fir (Abies alba Mill.). Rom J Meteorol 9:47-54

Rayback SA, Henry GHR, Lini A (2012) Multiproxy reconstructions of climate for three sites in the Canadian High Arctic using Cassiope tetragona. Clim Change 114:593-619. doi:10.1007/ s10584-012-0431-7

Rayner NA et al (2003) Global analyses of sea surface temperature, sea ice, and night marine air temperature since the late nineteenth century. J Geophys Res Atmos (1984-2012) 108:2-22. doi:10.1029/2002JD002670

Sano M, Furuta F, Kobayashi O, Sweda T (2005) Temperature variations since the mid-18th century for western Nepal, as reconstructed from tree-ring width and density of Abies spectabilis. Dendrochronologia 23:83-92. doi:10.1016/j.dendro.2005.08.003

Sano M, Buckley BM, Sweda T (2009) Tree-ring based hydroclimate reconstruction over northern Vietnam from Fokienia hodginsii: eighteenth century mega-drought and tropical Pacific influence. Clim Dyn 33:331-340. doi:10.1007/s00382-008-0454-y

Schmitz U (2004) Frost resistance of tomato seeds and the degree of naturalisation of Lycopersicon esculentum Mill. in Central Europe. Flora-Morphol Distrib Funct Ecol Plants 199:476-480. doi:10.1078/0367-2530-00176

Shen J, Zhang EL, Xia WL (2001) Records from lake sediment of Qinghai Lake mirror climatic and environmental changes of the past about 1000 years Quaternary. Science 21:508-513

Shi JF, Lu HY, Wan JD, Li SF, Nie HS (2009) Winter-half year temperature reconstruction of the last century using Pinus armandii Franch tree-ring width chronology in the eastern Qinling Mountains. Quat Sci 29:831-836. doi:10.3969/j. issn.1001-7410.2009.04.20

Singh J, Yadav RR, Wilmking M (2009) A 694-year tree-ring based rainfall reconstruction from Himachal Pradesh, India. Clim Dyn 33:1149-1158. doi:10.1007/s00382-009-0528-5

Song HM, Liu Y, Ni WM, Cai QF, Sun JY, Ge WB, Xiao WY (2007) Winter mean low temperture derived from tree-ring width in Jiu Zhai Gou region, China since 1750 A.D. Quat Int 27:486-491
Su HX, Axmacher JC, Yang B, Sang WG (2015) Differential radial growth response of three coexisting dominant tree species to local and large-scale climate variability in a subtropical evergreen broad-leaved forest of China. Ecol Res 30:1-10. doi:10.1007/s11284-015-1276-0

Takahashi K, Tokumitsu Y, Yasue K (2005) Climatic factors affecting the tree-ring width of Betula ermanii at the timberline on Mount Norikura, central Japan. Ecol Res 20:445-451. doi:10.1007/ s11284-005-0060-y

Tardif J, Brisson J, Bergeron Y (2001) Dendroclimatic analysis of Acer saccharum, Fagus grandifolia, and Tsuga canadensis from an old-growth forest, southwestern Quebec. Can J For Res 31:1491-1501. doi:10.1139/x01-088

Touchan R, Christou AK, Meko DM (2014) Six centuries of May-July precipitation in Cyprus from tree rings. Clim Dyn 43:32813292. doi:10.1007/s00382-014-2104-x

Vlam M, Baker PJ, Bunyavejchewin S, Zuidema PA (2014) Temperature and rainfall strongly drive temporal growth variation in Asian tropical forest trees. Oecologia 174:1449-1461. doi:10.1007/s00442-013-2846-X

Wang XM, Zhao XH, Gao LS, Jiang QB (2012) Relationship between climate and tree-ring chronology of Betula ermanii on tree-line in north slope of the Changbai Mountains. Chin J Appl Environ Biol 18:9-16

Wilson R, Miles D, Loader NJ, Melvin T, Cunningham L, Cooper R, Briffa K (2013) A millennial long March-July precipitation reconstruction for southern-central England. Clim Dyn 40:9971017. doi:10.1007/s00382-012-1318-z

Woodcock H, Bradley RS (1994) Salix arctica (Pall.): its potential for dendroclimatological studies in the High Arctic. Dendrochronologia 12:11-22

Xiao SC, Xiao HL, Zhou MX, Si JH, Zhang XY (2004) Water level change of the West Juyan Lake in the past 100 years recorded in the tree ring of the shrubs in the lake banks. J Glaciol Geocryol 26:557-562

Xu JC, Grumbine RE, Shrestha A, Eriksson M, Yang XF, Wang Y, Wilkes A (2009) The melting Himalayas: cascading effects of climate change on water, biodiversity, and livelihoods. Conserv Biol 23:520-530. doi:10.1111/j.1523-1739.2009.01237.x

Yang B, Qin C, Wang JL, He M, Melvin TM, Osborn TJ, Briffa KR (2014) A 3500-year tree-ring record of annual precipitation on the northeastern Tibetan Plateau. Proc Natl Acad Sci 111:29032908. doi:10.1073/pnas.1319238111

Yao TD, Qin DH, Tian LD (1996) Variations in temperature and precipitation in the past 2000 years on the Xizang (Tibet) Plateau-Guliya ice core record. Sci China 26:348-353

Yuan YJ, Li JF (1999) Reconstruction and analysis of 450 years' winter temperature series in the Urumqi River source of Tianshan Mountains. J Glaciol Geocryol 21(642):270

Zhang XL, Xu BQ, Xie Y, Wang M (2012) Climatic and environmental changes over the past about 300 years recorded by lake sediments in Taro co, southwestern Tibetan Plateau. J Earth Sci Environ 34:79-90

Zhang ZY, Wang ZG, Li WL, Chen Z (2013) Impacts of the SST Anomalies in the Western Pacific Warm Pool on the East Asia Circulation. Meteorol Environ Sci 36:61-64

Zhang KX, Pan SM, Cao LG, Wang Y, Zhao YF, Zhang W (2014) Spatial distribution and temporal trends in precipitation extremes over the Hengduan Mountains region, China, from 1961 to 2012. Quat Int 349:346-356. doi:10.1016/j.quaint.2014.04.050

Zhang RB et al (2015) Dendroclimatic reconstruction of autumnwinter mean minimum temperature in the eastern Tibetan Plateau since 1600 AD. Dendrochronologia 33:1-7. doi:10.1016/j. dendro.2014.09.001 